\title{
Right Coronary Artery - Looped, Astray and Muzzled: A case report
}

\author{
Anitha Guru*, Naveen Kumar, AM Prasad \\ From World Society of Cardiothoracic Surgeons 25th Anniversary Congress, Edinburgh \\ Edinburgh, UK. 19-22 September 2015
}

\section{Background/Introduction}

The right coronary artery (RCA) arises from the right aortic sinus. In its course in relation to the atrioventricular groove (AVG), it is submerged in the adipose tissue of the epicardium. It continues towards the posterior interventricular groove often crossing the crux of the heart.

\section{Aims/Objectives}

To trace the RCA and determine the variation in its course

\section{Method}

The heart of a well embalmed male cadaver is dissected to trace the RCA in the right AVG. The branches are traced to determine the variation in the course of the RCA.

\section{Results}

During the exposure of RCA, the right AVG was found unoccupied. Further probing did reveal the atrial branches bearing a proximal origin, but no ventricular branches in the right AVG. On tracing the atrial branches to their origin, the RCA was visible. The RCA had a normal origin from the right aortic sinus. Soon after, instead of being submerged in the adipose tissue, it produced a unique pattern of looping with two corners and the loop rose above the surface of the heart. The space underneath the loop was filled with adipose tissue. The RCA then exited the AVG and went astray into the myocardium of the right ventricle. Within the wall of right ventricle, the artery initially pursued a superficial course giving rise to ventricular branches in the direction of the left ventricle. Few of the ventricular branches produced elevations on the surface of the right

Department of Anatomy, Melaka Manipal Medical College, Manipal Campus, Manipal University, Manipal, Karnataka, 576104, India ventricle. For the further part, the RCA did not enter the AVG and hence did not reach the crux. Due to its intra-myocardial course, the right marginal artery was not seen on the surface of the heart. The coronary sinus was the sole relation to the AVG.

\section{Discussion/Conclusion}

In this case, the RCA and its ventricular branches appear muzzled by the myocardium of the right ventricle. Such a variation in the course of RCA accompanied by the unique looping pattern is rare. It may pose a tough challenge to the radiologists and cardiologists in performing various procedures such as coronary stenting involving the RCA

Published: 16 December 2015

doi:10.1186/1749-8090-10-S1-A27

Cite this article as: Guru et al:: Right Coronary Artery - Looped, Astray and Muzzled: A case report. Journal of Cardiothoracic Surgery 2015 10(Suppl 1):A27.

Submit your next manuscript to BioMed Central and take full advantage of:

- Convenient online submission

- Thorough peer review

- No space constraints or color figure charges

- Immediate publication on acceptance

- Inclusion in PubMed, CAS, Scopus and Google Scholar

- Research which is freely available for redistribution 